\title{
Artificial arenite from wastes of natural sandstone industry
}

\author{
C. Conde-Vázquez, ${ }^{a}$ O. de Miguel-San Martínª , G. García-Herbosa ${ }^{\mathrm{b}} \bowtie$ \\ a. Departamento de I+D. Areniscas Stone. Centro I+D. Vilviestre del Pinar. (Burgos. Spain). \\ b. Química Inorgánica. Facultad de Ciencias. Universidad de Burgos. (Burgos. Spain). \\ $\triangle$ gherbosa@ubu.es
}

\author{
Received 17 November 2017 \\ Accepted 15 June 2018 \\ Available on line 16 January 2019
}

\begin{abstract}
An artificial arenite was developed from the waste of the sandstone industry. The waste sandstone was treated to obtain different grain sizes that were recombined to reproduce the natural texture. An unsaturated polyester resin was added to the mixture of grains and the cement polymerization was initiated with methyl ethyl ketone peroxide. The product was compacted under pressure of 1.5 to $9.7 \mathrm{MPa}$ and cured at $70^{\circ} \mathrm{C}$. The result was a new material with the appearance of the natural rock. Artificial sandstones were studied by SEM microanalysis, petrography study and XRF analysis. Measurements of flexural strength (9.9 MPa), apparent density $\left(2110 \mathrm{~kg} / \mathrm{cm}^{3}\right)$, open porosity $(7.6 \%)$, water absorption $(1.2 \%)$, abrasion resistance $(19 \mathrm{~mm})$ and photostability $(\mathrm{AE} *=-0.009)$ were carried out. The influence of the design of the mixture and its composition (fraction of aggregates, resin content and pressure) on the texture and the mechanical properties was studied.
\end{abstract}

KEYWORDS: Artificial sandstone; Waste treatment; Polyester polymer; Flexural strength; Mechanical properties.

Citation/Citar como: Conde-Vázquez, C.; de Miguel-San Martín, O.; García-Herbosa, G. (2019) Artificial arenite from wastes of natural sandstone industry. Mater. Construcc. 69 [333], e178. https://doi.org/10.3989/mc.2019.12317.

RESUMEN: Arenita artificial a partir de residuos de la industria de arenisca. Se ha desarrollado una arenita artificial a partir de los residuos de la industria de la arenisca. Los residuos se trataron para obtener diferentes tamaños de grano que después se recombinaron para reproducir la textura natural. Se añadió una resina de poliéster insaturado a la mezcla de granos y se inició su polimerización con peróxido de metil etil cetona. El producto fue compactado bajo presión de 1.5 a $9.7 \mathrm{MPa}$ y curado a $70{ }^{\circ} \mathrm{C}$. El resultado fue un nuevo material con la apariencia de la roca natural. Las areniscas artificiales se estudiaron mediante microanálisis SEM, estudio de petrografía y análisis XRF. Se llevaron a cabo mediciones de la resistencia a la flexión (9.9 MPa), la densidad aparente $(2110 \mathrm{~kg} / \mathrm{cm} 3)$, la porosidad abierta $(7.6 \%)$, la absorción de agua (1.2\%), la resistencia a la abrasión $(19 \mathrm{~mm})$ y la fotoestabilidad $\left(\mathrm{AE}^{*}=-0.009\right)$. Se estudió cómo influían los parámetros de la síntesis (fracción de agregados, contenido de resina y la presión) sobre la textura y las propiedades mecánicas.

PALABRAS CLAVE: Arenisca artificial; Tratamiento de residuos; Polímero de poliester; Resistencia a la flexión; Propiedades mecánicas.

ORCID ID: C. Conde-Vázquez (http://orcid.org/0000-0003-3155-3719); O. de Miguel-San Martín (http://orcid. org/0000-0003-0036-2960); G. García-Herbosa (http://orcid.org/0000-0002-2863-1272)

Copyright: (C) 2019 CSIC. This is an open-access article distributed under the terms of the Creative Commons Attribution 4.0 International (CC BY 4.0) License. 


\section{INTRODUCTION}

The arenites (geological name sandstone) are natural rocks formed by deposition of sediments that were eroded in mountains and then transported, deposited, compacted and consolidated in a geological basin to form the final rock. The composition of the sediments can include inorganic and organic materials coming from both plants and other living forms transported by water or wind. The result of such a mixture of components led to the final rock with the clastic structure as shown in Figure 1. The fabric contains first a set of clasts (grains) in the range $2 \mathrm{~mm}$ to $0.0625 \mathrm{~mm}$ of diameter, forming the framework of the rock. Second, a matrix formed by detrital material that is a paste produced by infiltration into the interstices. Third, cement originated through chemical precipitation. Finally some porosity remained in the structure (1). The combination of the different and available minerals in the nature led to many classes of arenites (2).

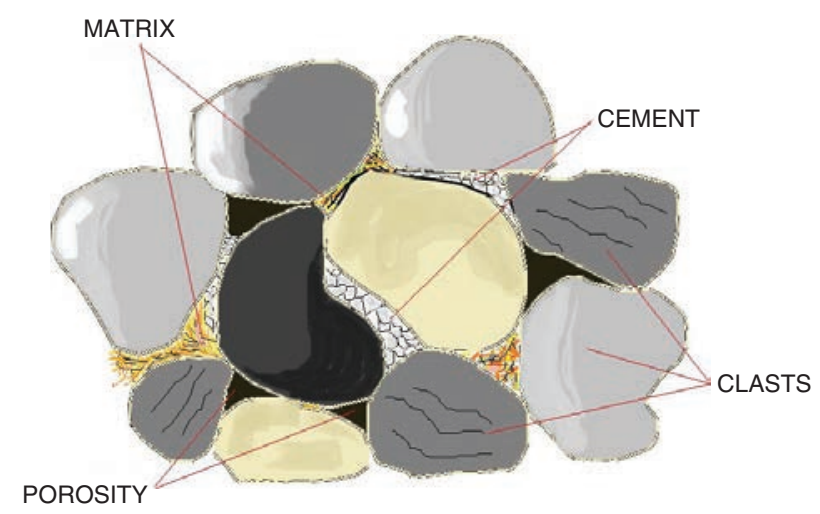

Figure 1. Structure of an arenite based on Mocoroa, 2010 (3).

The natural deposits of arenites are usually of small size and depth when compared to quarries of granite or marble, and its use as raw material depends on the type of sediment that builds the rock (4-7). In the field of natural stone, it is well known that the raw material that reaches the end consumer is approximately $25 \%$ of the initial potential of the quarry (8). This means that the remaining $75 \%$ are wastes, classified into different types of tailings: blocks, leftover and sludge which all together or apart produce a significant environmental impact. This research is motivated by the need to tap into this $75 \%$ of natural resources. The natural arenites used in this work come from Spain, which is the seventh largest producer of natural stone after China, India, Turkey, Iran and Italy, and currently very close to Brazil. The sandstones used in our research come from the province of Burgos, which supplies the $7 \%$ of the country's natural production $(9,10)$.
The residues here used come from the geological basin of Cameros that was formed during the Early Cretaceous geologic period (11-13). They have siliciclastic nature, i.e. consisting mainly of clasts of quartz, feldspar and lithic fragments (14).

The heterogeneous composition of the residues hampers their use as conventional aggregates, since they would require washing and grading processes economically unviable. On the basis of agglutination of wastes with a binder to form aggregates, new materials have been developed by using the residues of other rocks like marble, granite or limestone (1519). There have been studies to develop products called artificial sandstone, but these products either do not present geological structure of sandstones or do not use waste sandstones. The binders are usually cements or organic resins. The process may include or not compaction. In all cases the final product is an agglomerate material that fails to reproduce the appearance of the source rock.

This research pretends to synthesize artificial arenites (in the geological sense) using the quarry waste sandstones and to reproduce as exactly as possible the rock from which they came.

\section{MATERIALS AND METHODS}

\subsection{Leftover and waste rock}

The waste and leftover rocks had different sizes and origins: those from the quarry had sizes up to $7 \mathrm{~m}^{3}$. Those coming from the factory were classified as minor cuts or leftover fragments. The sludge was collected from the water treatment plant. All the residues used to synthesize artificial arenites came from a quarry of siliciclastic sandstone in the town of Vilviestre del Pinar (Latitude: $41.951024^{\circ} \mathrm{N}$ and Longitude: $3.078283^{\circ} \mathrm{W}$ ).

Both waste, stone blocks and leftover fragments, were crushed to form sands. It was important not to grind the grains to smaller sizes than those of the original stone clasts. In the next step these sands were passed through a sieving sequence of eleven different sizes: $2.5 / 2 / 1.12 / 0.425 / 0.300 / 0.200$ / $0.160 / 0.125 / 0.063 / 0.056 / 0 \mathrm{~mm}$. The sludge was dried outdoors and then passed through the same sieving sequence. Once classified all sands by grain size they were dried in an oven at $70^{\circ} \mathrm{C}$.

\subsection{Cement}

The cement was used to simulate the natural cementing rock as shown in Figure 1. The function of the cement is to bind the clasts to build the framework of the artificial rock. In this work a commercial unsaturated polyester resin (orthophthalic polyester resin supplied as H6DY by the company Hegardt S.L.) with a styrene content of 
$29 \%$ and catalyzed with $2 \%$ cobalt(II) octanoate was selected. Artificial binders must always be colored using special pigments to simulate the color of natural cementing; in this case, $1.5 \%$ by weight of a pigment paste with RAL 1015 (manufactured by Hegartd S.L.) was added to the polyester resin. The curing of the pigmented resin was initiated by addition of $2 \%$ methylethylketone peroxide (PMEK) leading to gelification after 8-11 minutes at $20^{\circ} \mathrm{C}$.

\subsection{Sample preparation}

A sample of $72.1 \mathrm{~g}$ of sand with GR5 granulometry was taken (Table 1), and mixed to homogenize. A mixture of $11.7 \mathrm{~g}$ of the H6DY resin and $1.3 \mathrm{~g}$ of RAL 1015 pigment was poured in another beaker. After stirring vigorously with a glass rod for 5-10 seconds the mixture turned uniformly coloured. Then, $0.3 \mathrm{~g}$ of initiator (PMEK) was added and again stirred vigorously for 15 seconds. At this point the sands were added over the pigmented resin. The mixture was further stirred for about 30 seconds until the resin has soaked evenly to all sands. The mixture was poured onto a metal mold $7 \times 7 \times 5 \mathrm{~cm}$ as shown in Figure 2 , which had been previously covered inside with a release film. The mixture was spread to fill the mold and then carried to a press where a compaction speed of $1.5 \mathrm{MPa} / \mathrm{s}$ up to $29.1 \mathrm{MPa}$ was applied. The pressure was kept for 30 seconds. After this time, the pressure was released and the specimen removed out of the mold and placed in the oven at $70{ }^{\circ} \mathrm{C}$ for $24 \mathrm{~h}$. After this time, a test piece of dimensions $7 \times 7 \times 0.8 \mathrm{~cm}$ with the same texture to the natural stone was obtained.

The characteristics of the microanalysis were determined by SEM and by petrographic study in accordance with UNE EN 12407: 2007 standard (20). The X-ray fluorescence analysis (XRF) was carried out with a Thermo Electron Corporation equipment with ARL ADVAT XP XRF sequentially with Claisse Fluxy press. The flexural strength was determined in accordance with the UNE EN12372: 2006 standard (21). 10 samples of $18 \times 5 \times 3 \mathrm{~cm}$ were used for natural rock, and for artificial sandstone were used ten $15 \times 5 \times 0.8 \mathrm{~cm}$ samples manufactured with molds of size $15 \times 5 \times 5 \mathrm{~cm}$ prepared following the procedure described above. To study the influence of compaction pressure on the flexural strength of artificial sandstones, another five sets of 10 specimens manufactured at compaction pressures of 1.5 / 3.2 / 4.0 / 6.8 / 9.7 MPa were made.
The apparent density and open porosity strength were determined in accordance with the UNE EN 1936: 2007 standard (22), and the absorption of water at atmospheric pressure was determined in accordance with the UNE EN 13755: 2008 standard (23). In the determination of these parameters, 6 samples of $5 \times 5 \times 5 \mathrm{~cm}$ for natural sandstone and 6 samples of $5 \times 5 \times 3 \mathrm{~cm}$ obtained in molds of $5 \times 5 \times 5 \mathrm{~cm}$ for the artificial rock were used. The abrasion resistance was determined in accordance with the annex A: Capon Test of UNE EN 14157:2004 standard (24). This method has been used in natural stone to determine the hardness of the rock and it is a measure of the cohesiveness of its constituents. The test is based on the penetration of a $7 \mathrm{~cm}$ wide stainless steel disc at the stone surface. The softer the rock, the deeper is the penetration of the disc and it makes a wider mark on the sample surface. The resulting value is determined as the width of the indentation. 6 samples of $15 \times 15 \times 2 \mathrm{~cm}$ of natural rock and 6 samples of $15 \times 5 \times 0,8$ of artificial rock were used. In order to check the photostability of artificial arenite, a solar camera (Solatron model by CCI) with quartz/mercury lamps has been used. 10 test pieces of size $7 \times 7 \times 0.8 \mathrm{~cm}$ were used. They were placed in the chamber to $41 \mathrm{~cm}$ of radiant window (position lamp). The average irradiance of the lamps was $8500 \mathrm{~W} / \mathrm{m}^{2}$ and the test lasted for 600 hours. The evaluation of the photostability was carried out using a Hunterlab Miniscan XE Plus spectrophotometer to measure the CIELAB parameters $(\mathrm{L} *$, $a *$ and $b *)$. Measures were taken before and after the test, and the $\mathrm{AE}$ was determined.

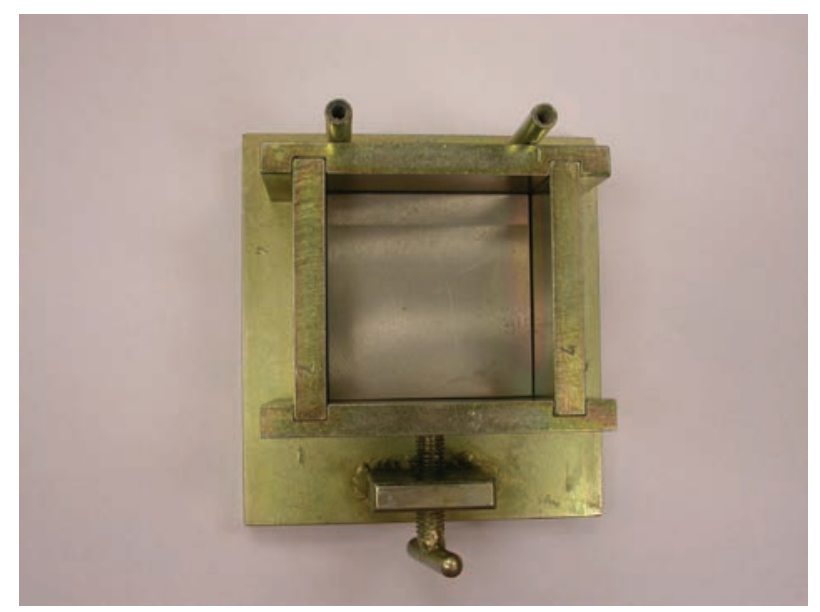

FIGURE 2. Removable stainless steel mold of $7 \times 7 \times 5 \mathrm{~cm}$.

TABLE 1. Sorting GR5

\begin{tabular}{lllllllllll}
\hline Diameter $(\mathbf{m m})$ & $\mathbf{2 . 0 0}$ & $\mathbf{1 . 1 2}$ & $\mathbf{0 . 4 2 5}$ & $\mathbf{0 . 3 0}$ & $\mathbf{0 . 2 0 0}$ & $\mathbf{0 . 1 6 0}$ & $\mathbf{0 . 1 2 5}$ & $\mathbf{0 . 0 6 3}$ & $\mathbf{0 . 0 5 6 6}$ & $\mathbf{0}$ \\
\hline Weight $(\mathrm{g})$ & 0.83 & 0.94 & 12.05 & 17.15 & 16.57 & 7.21 & 5.70 & 7.73 & 1.85 & 2.12 \\
\hline
\end{tabular}




\section{RESULTS AND DISCUSSION}

\subsection{Microanalysis}

The texture of the artificial arenite was substantially equal to the natural rock as shown by scanning electron microscope Figure 3 (a) y (b). Optical magnifying of the image displayed that the cementing was different. In the natural rock, see Figure 3 (c), a texture with turbid appearance due to the matrix is observed. In artificial arenite the cement appears cleaner and smoother than in the natural rock, Figure 3 (d). With further magnification, the connections between clasts were observed in more detail. In the natural arenite in Figure 3 (e) we can see the appearance of the matrix due to sedimentation of
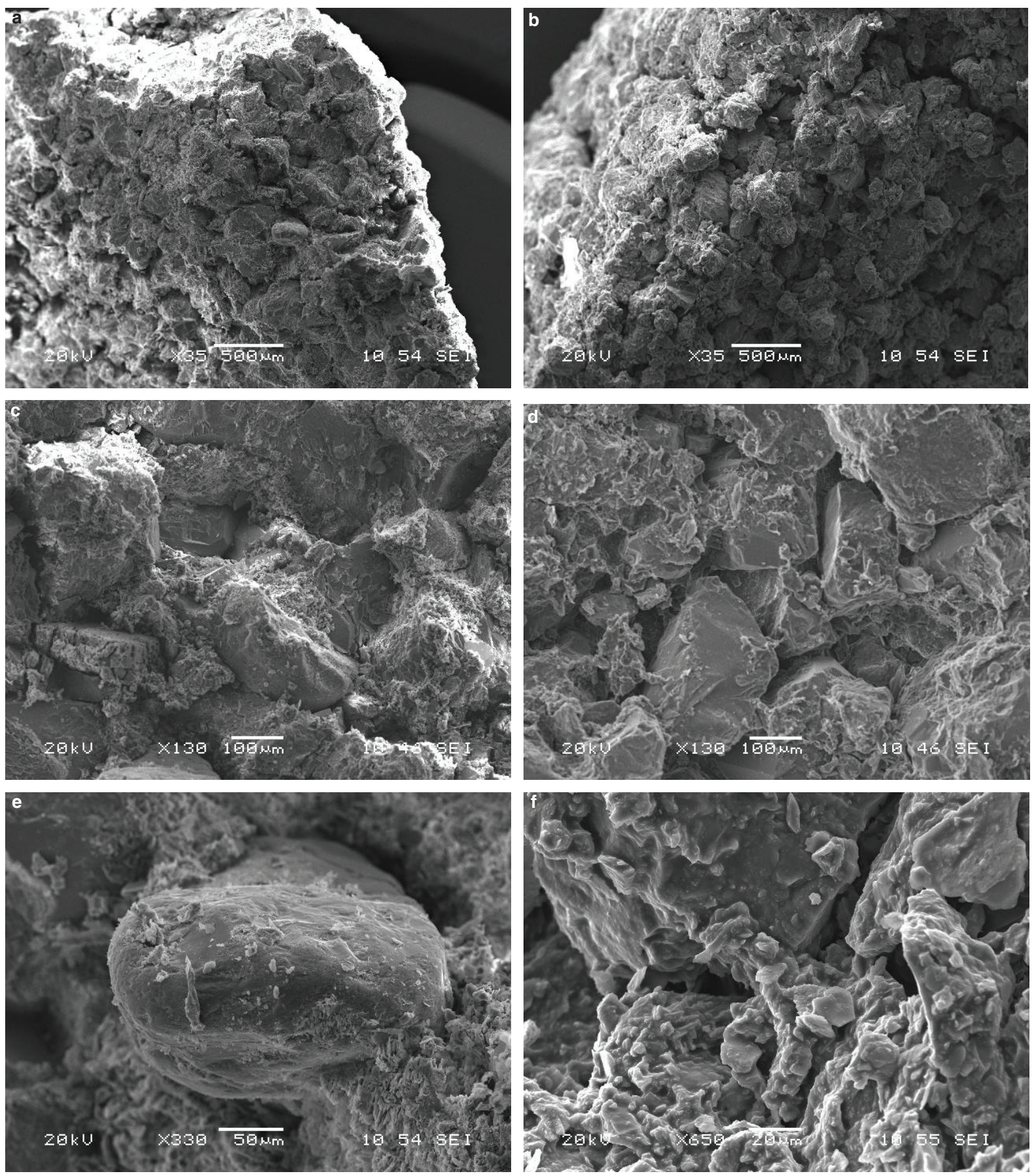

FIGURE 3. SEM micrographs of natural arenite (a), (c), (e) and of artificial arenite (b), (d), (f). 
clay minerals with siliceous cement, which gives a dirty look. However, in the artificial arenite of Figure 3 (f) the organic cement exhibits a continuous wrapping of the clasts. We suggest that this covering of the clasts increases their binding points and could explain why the artificial arenite presents better mechanical properties than the natural rock. In addition, the mantle formed by the organic cement partially seals many of the pores and the consequence is a less open porosity as explained above.

\subsection{Petrographic study}

The petrographic microscope observation of thin sections of these materials showed the differences and similarities between textures. The mineralogical composition of natural rock is $65 \%$ quartz (single crystals), feldspars 30\% (including altered plagioclase, orthose and microcline) and 10\% rock fragments, with a moderately well-sorted sediment, which classifies it as an arkose (Folk, 1974 (2)). The chemical composition of leftover rock, analyzed by $\mathrm{X}$ ray fluorescence XRF is shown in the Table 2 .

The rock has a dense packing as shown in Figure 4. The contact among grains (grain-supported-fabric) is concave-convex. The matrix appears heterogeneously distributed in the sheet and the cement is only found on the grain boundaries (pore lining). Artificial arenite presents a floating packing, the clasts are surrounded by organic cement. A compaction pressure of $1.5 \mathrm{MPa}$ was enough to approximate the clasts. The difference between the two materials (natural and artificial arenites) is due to

TABLE 2. Chemical composition of stone leftover fragments

\begin{tabular}{lcccccc}
\hline Component & $\mathrm{SiO}_{2}$ & $\mathbf{A l}_{2} \mathbf{O}_{3}$ & $\mathbf{K}_{2} \mathbf{O}$ & $\mathrm{Fe}_{2} \mathbf{O}_{3}$ & $\mathbf{C a O}$ & Others \\
\hline Weight (\%) & 67.9 & 16.6 & 3.2 & 3.0 & 2.0 & $<3$ \\
\hline
\end{tabular}
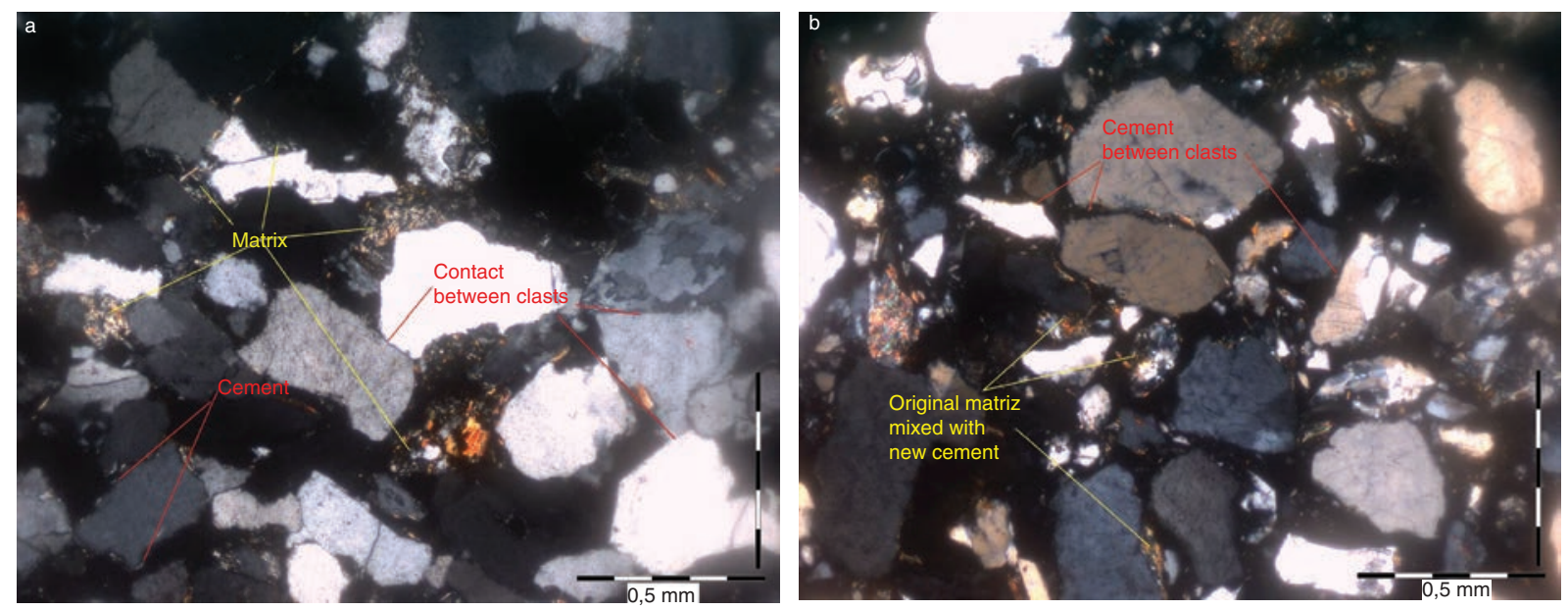

Figure 4. Polarizing microscopy micrographs in cross nicols, $5 \times$ objectives. (a) Natural arenite. (b) Artificial arenite. 
very high porosity and a poorer sorting. We suggest that this result is likely due to the breaking of the clasts in the grinding process. In order to reproduce the original texture of the rock, the recombination of the different grain sizes was carried out to get the appropriate sorting, labeled as GR5.

In the case of the sandstone of the geological basin of Cameros, the best result was obtained when using the GR5 classification as shown in Figure 6. In this research work, a total of 47 different grain size distribution were developed by combination, whose nomenclatures range from GR1 to GR47. (Figure 7) With all of them, the 156 synthesis variants were carried out during all, obtaining information on the effect of size particles on the texture. Small variations in the concentrations of the GR5 components reproduced the original texture but, when the deviations were larger, the appearance was no longer natural stone.

\subsection{Effect of the cement concentration on the aspect}

The natural rock grains occupy only $80-90 \%$ of total volume. The remaining interstitial space is in part filled by a mixture of cement-matrix composed mainly of silica minerals and argillaceous sediments. Considering the volume ratio between grains and fillers, a concentration of artificial cement between 10 to $20 \%$ by weight was tested. The ideal concentration to reproduce Cameros arenites was in the range $12 \%$ to $14 \%$, being the optimal value $13.7 \%$. We observed that for concentrations lower
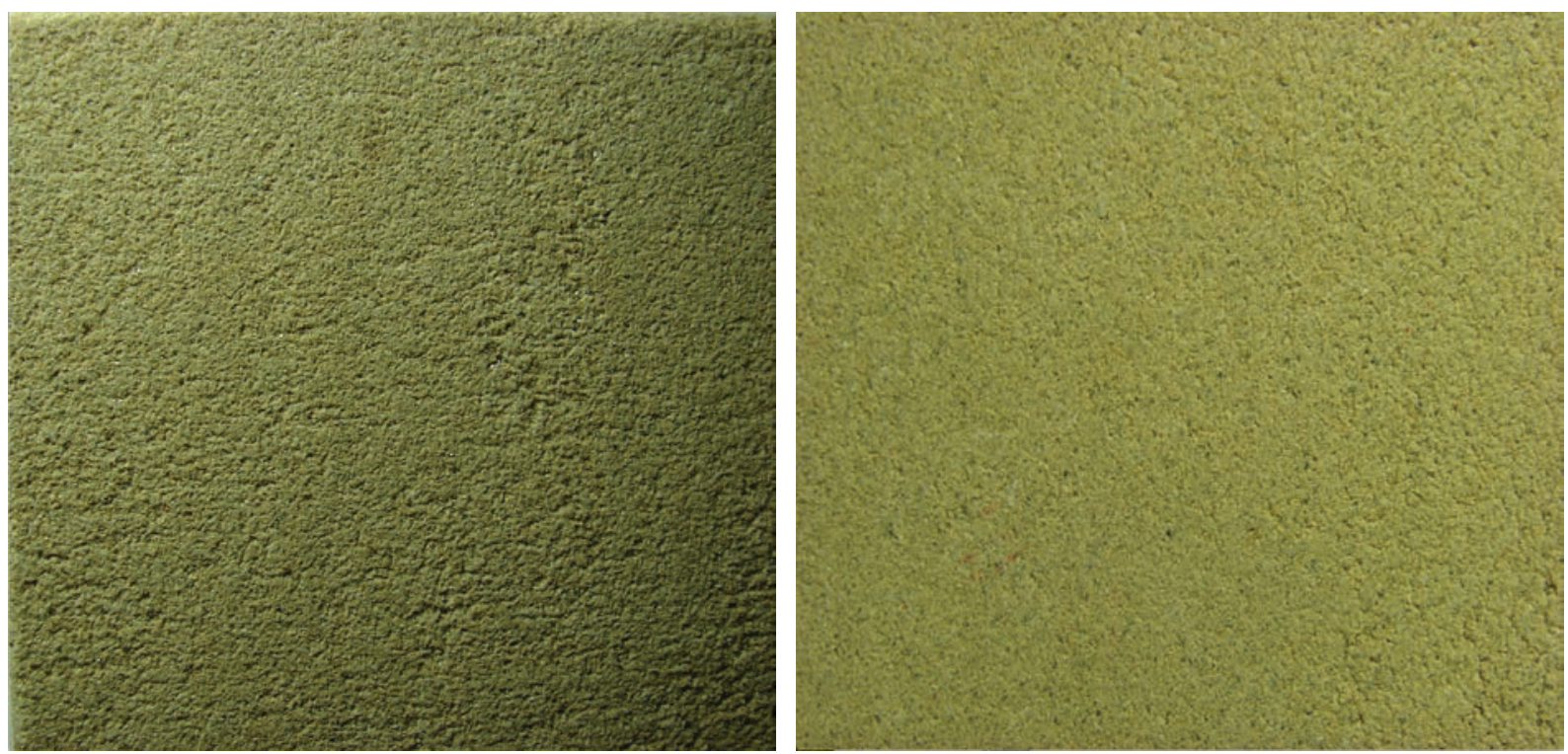

FIGURE 6. Comparison of texture of natural arenite (left) and artificial arenite with GR5 sorting (right). Surfaces of $3 \times 4 \mathrm{~cm}$.

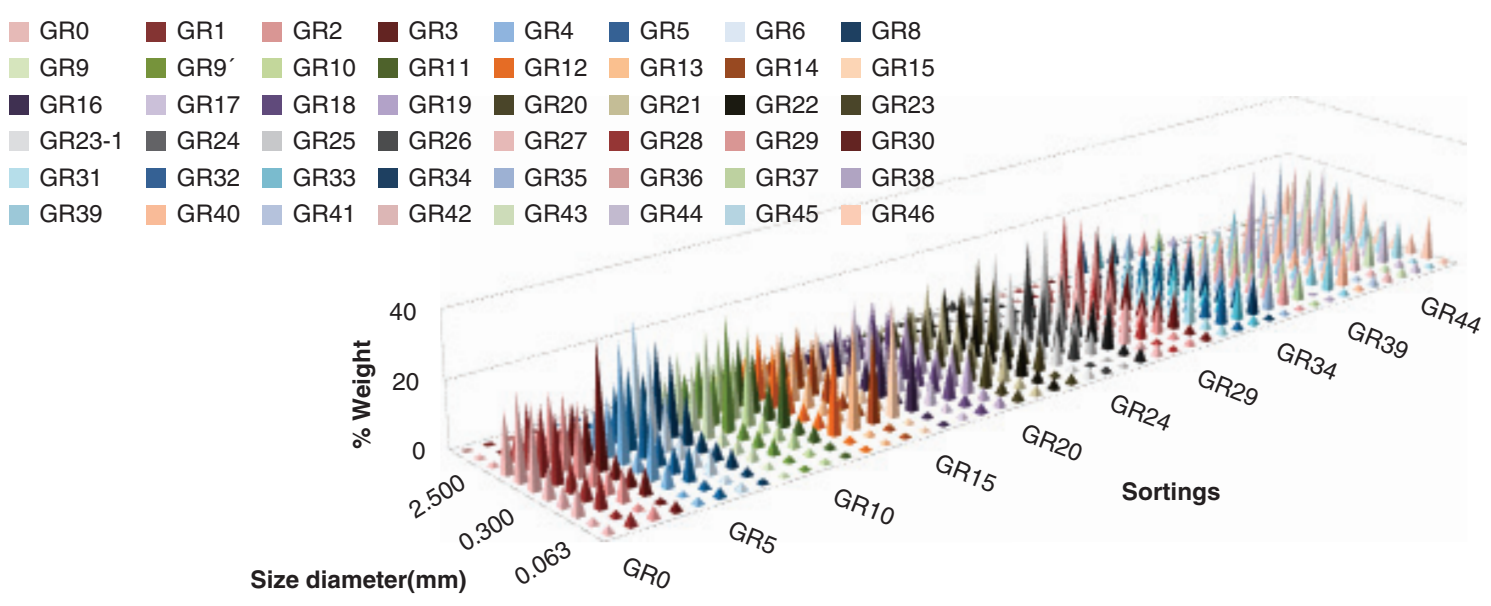

FIGURE 7. Sortings develeped. 
than $12 \%$, the resin was unable to fully consolidate the artificial arenite. For concentrations above 15\%, the resin was in excess and formed undulations on the surface of the sample.

\subsection{Effect of the compaction pressure on the aspect and the flexural strength}

It was observed that any of the indicated pressures reproduced the natural texture of the rock. When the flexural strength of these specimens was measured under load, it was observed that the resistance increased with the compacting pressure, but not linearly. As depicted in Figure 8, a compaction pressure of $1.5 \mathrm{MPa}$ led to mechanical strength of 9.9 MPa. This value is three times higher and greatly improves the flexural strength of the natural rock (3.3 MPa). In short, the artificial sandstones obtained with this procedure are harder materials than the raw material source and they are very promising in future applications.

\subsection{Apparent density, open porosity and water absorption test}

The observed results indicated that the artificial arenite density was $2110 \mathrm{~kg} / \mathrm{cm}^{3}$ that can be compared with $2260 \mathrm{~kg} / \mathrm{cm}^{3}$ of the natural rock. This difference may be due to two factors. First, the sorting and packaging are not as dense as natural stone, and second, the natural siliceous cement is replaced by the less dense resin. However, the value of the density obtained is in the range of sandstones of the Cameros basin that fluctuate from 2090 to $2260 \mathrm{~kg} / \mathrm{cm}^{3}(25)$.

When the open porosity was checked, artificial arenite GR 5 showed an open pore volume of $7.6 \%$ that is approximately half of the value of natural stone $(14.5 \%)$, but however is not more compact, as it has a lower density as discussed above.

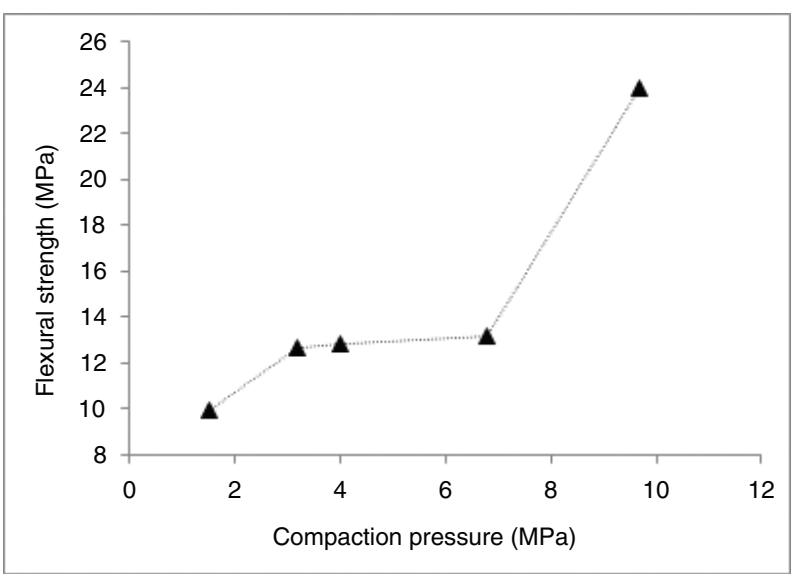

Figure 8. Flexural strength of artificial arenites versus compaction pressure.
To understand this difference, we suggest that in the artificial arenite the resin has covered part of the pore openings on the surface thus preventing the entry of water used in the assays to determine the pore volume.

The weight percent of water absorption found for artificial arenite is $1.2 \%$, four times lower than that of natural stone $(4.7 \%)$. Once more, the effect of the resin covering pores may explain the lower value for the water absorption parameter. It can be concluded that the artificial arenite has better waterproof properties than natural rock because of the artificial cement used.

\subsection{Abrasion resistance using Capon Test}

The result obtained for the artificial sandstone was $19 \mathrm{~mm}$, which is a little lower than the value obtained for natural rock $(21 \mathrm{~mm})$. The result is consistent, since both materials are made of the same minerals (Mosh hardness) and have almost the same density, so this result shows that the artificial cement fixes the framework of it a little better than the natural one.

\subsection{Photostability test}

The natural rock is stable to sunlight because its mineral constituents so are. In artificial arenite an organic element (resin) has been introduced and may be susceptible to aging under sunlight.

Once carried out the photostability test the specimens showed the same tenacity than before the test. They are resistant to manual bending and no color changes were observed to the naked eye. The color parameters were measured with a spectrophotometer and only small variations were observed, Figure 9. Specimens with solar aging become clearer $\Delta \mathrm{L}^{*}=0.397$ (the coordinate $\mathrm{L}^{*}$ is shifted to larger values). The parameter $\mathrm{a}^{*}$ shows a shift to green, $\Delta a^{*}=-0.366$ while the parameter $b^{*}$ fluctuates to the blue or to the yellow depending on the sample, $\Delta b^{*}=-0.400$. To the light of these results it can be concluded that the action of sunlight on our artificial sandstones is not relevant, $\Delta \mathrm{E}^{*}=-0.009$.

\section{CONCLUSIONS}

This research reports a method of "artificial genesis" to form artificial arenites/sandstones from the waste and the remaining sandstones from industries. The waste is defragmented, only a crushing is necessary, and the process does not require washing treatments or mineral separation. The separated sand fractions recombine until the natural frame is emulated to form the new artificial sandstones. Up to $80 \%$ by weight of the new material is reused waste, so the positive environmental impact is considerable. Although the initial objective of the study 

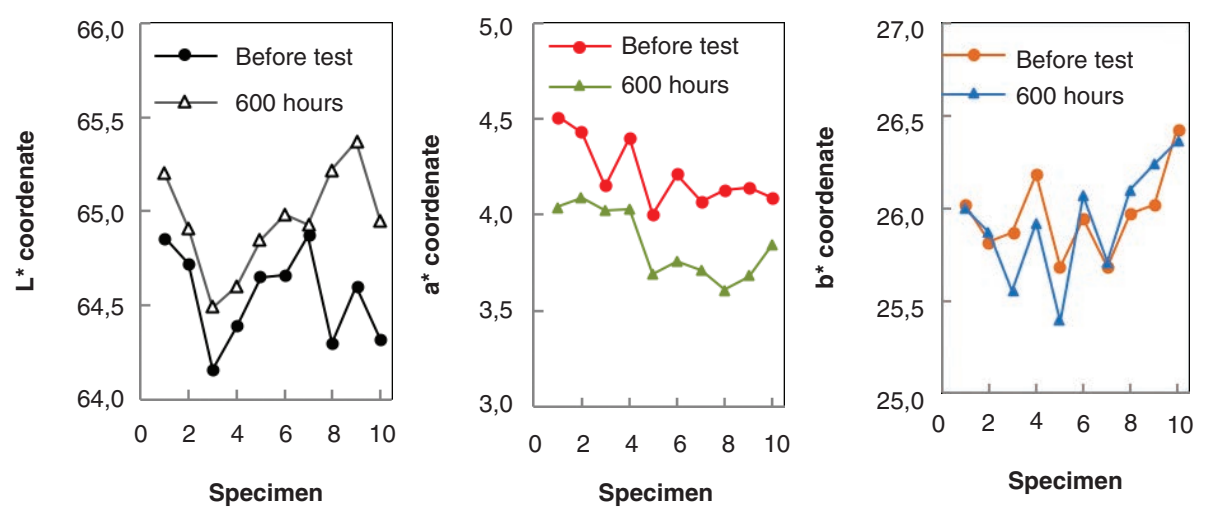

Figure 9. Photostability test: shift of the coordinates $L^{*}, a^{*}, b^{*}$.

was to reproduce the sandstones of the Cameros Basin, it was later discovered that the methodology could be extrapolated to reproduce any sandstone anywhere in the world. The result is a new material whose density and appearance are those of natural rock. The incorporation of an organic cement (resin) provides the artificial sandstone with greater mechanical resistance than those of natural sandstone. The conclusive result is an artificial sandstone whose appearance is equal to that of the original natural rock. It has been studied how textures and physico-mechanical properties vary depending on the synthesis conditions, which allows designing and manufacturing customized sandstones. The properties of this material are much better than those of the sandstone of origin, which gives it an advantage to be able to go on the market. In addition, the industrial process necessary to manufacture artificial sandstones is practically available, there are already presses capable of generating pressures of 1.5-10 MPa, and the curing can be carried out in continuous storage ovens already known in the sector of quartz and marble compacts.

\section{ACKNOWLEDGEMENTS}

The authors gratefully acknowledge to the Spanish Ministerio de Medio Ambiente (A511/2007/1-09.2), to the Junta de Castilla y León (04/07/BU/0049) and to the European Regional Development Fund (ERDF) for financial support.

\section{REFERENCES}

1. Pettijohn, F.J.; Potter, P.E.; Siever, R.; (1987) Sand and sandstone, Springer-Verlag, New York.

2. Folk, R.L.; (1974) Petrology of sedimentary rocks, Hemphill Publishing Company, Austin, Texas 78703.

3. Mocoroa, J. A.; (2010) Análisis de la procedencia en depósitos arenosos. Sedimentología: del proceso físico a la cuenca sedimentaria. , Ed A. Arche. CSIC, Madrid.

4. López-Gómez, J.; Arche, A.; De la Horra, R.; GalánAbellán, B.; Barrenechea, J.F.; (2011) Permian-Triassic continental rocks of the SE Iberian Ranges: Architecture, tectonics and geochemical characteristics in the context of a rift basin, Post-Meeting Field trips Guidebook, 28th IAS Meeting GeoGuías. Journal of Iberian Geology, Zaragoza (Spain), pp. 11-43.

5. Bhatia,M.R.; (1983) Plate-tectonics and geochemical composition of sandstones. J. Geol. 91, 611-627. https://doi. org/10.1086/628815.

6. Chang, J.C.; Liao, J.J.; Pan, Y.W.; (2008) Bearing behavior and failure mechanism of a shallow foundation located on/ behind the crest of a poorly cemented artificial Sandstone. Int. J. Rock Mech. Min. Sci. 45, 1508-1518. https://doi. org/10.1016/j.ijrmms.2008.01.013.

7. T. Klimentos, A. Parker, (1988) The preparation (by an epoxy-resin method) and physical-properties of artificial sandstones. Sediment. Geol. 59, 307-312. https://doi. org/10.1016/0037-0738(88)90083-8

8. Tomkasic, I.; Krsinic, A.; (2010) Some important facts for estimation of natural stone deposits during the exploration, Global Stone Congress.

9. Stone Sector, (2010) Industria Italiana e Congiuntura Internazionale, https://issuu.com/thetis/docs/stone_sector_ $2010 ? \mathrm{e}=2145441 / 5157341$ (last accessed 19/09/2016).

10. Minerva, (2013) Estadísticas de producción minera/Rocas ornamentales, https://sedeaplicaciones.minetur.gob.es/ minerva/GenerarInformes.aspx /(last accessed 19/09/2016).

11. Arribas, J.; Alonso, A.; Mas, R.; Tortosa, A.; Rodas, M.: Barrenechea, J.F.; Alonso-Azcárate, J.; Artigas, R.; (2003) Sandstone petrography of continental depositional sequences of an intraplate rift basin: Western Cameros Basin (North Spain). J. Sediment. Res. 73, 309-327. http://dx.doi. org/10.1306/082602730309.

12. González-Acebrón, L.; Arribas, J.; Mas, R.; (2007) Provenance of fluvial sandstones at the start of Late JurassicEarly Cretaceous rifting in the Cameros Basin (N. Spain). Sediment. Geol. 202, 138-157. https://doi.org/10.1016/j. sedgeo.2007.05.008.

13. Salomon, J.; (1982) Les formations continentales du bassin de Soria (NW chaines ibériques) au Jurassique superiurCretace inferior. Relations entre tectonique et sedimentation. J. Iber. Geol. 8, 167-185.

14. Barranechea, J.F.; Rodas, M.; Mas, J.R.; (1995) Clay mineral variations associated with diagenesis and lowgrade metamorphism of early Cretaceos sediments in the Cameros Basin, Spain. Clay Miner. 30, 119-133. http:// dx.doi.org/10.1180/claymin.1995.030.2.04.

15. Ates, E.; Barnes, S.; (2012) The effect of elevated temperature curing treatment on the compression strength of composites with polyester resin matrix and quartz filler. Mater. Des. 34, 435-443. https://doi.org/10.1016/j. matdes.2011.08.042.

16. Shirazi, E.K.; Marandi, R.; Afshar, N.; Alibabaie, M.; Sooki, A.; (2012) Reusing artificial stone waste in concrete as a filler of fine aggregates. J. Food, Agri. Environ. 10, 989-992. http://dx.doi.org/10.3989/mc.2007.v57.i286.45. 
17. Chang, F.C.; Lee, M.Y.; Lo, S.L.; Lin, J.D.; (2010) Artificial aggregate made from waste stone sluge ang waste silt. $J$. Environ. Manage. 91, 2289-2294. https://doi.org/10.1016/j. jenvman.2010.06.011.

18. Lee, M.Y.; Ko, C.H.; Chang, F.C.; Lin, J.D.; Shan, M.Y.; Lee, J.C.; (2008) Artificial stone slab production using waste glass, stone fragments and vacuum vibratory compaction. Cement Concrete Comp. 30, 583-587. https://doi. org/10.1016/j.cemconcomp.2008.03.004.

19. San-José, J.T.; Frías, M.; (2007) High performance polymer concrete. Mater. Construcc. 57, 29-39.

20. EN 12407, (2007) European Committee for Standardization. Natural stone test methods. Petrographic examination. AENOR.
21. EN12372, (2006) European Committee for Standardization. Natural stone test methods. Determination of flexural strength under concentrated load. AENOR.

22. EN 1936, (2006) European Committee for Standardization. Natural stone test methods. Determination of real density and apparent density, and of total and open porosity. AENOR.

23. EN 13755, (2008) European Committee for Standardization Natural stone test methods. Determination of water absorption at atmospheric pressure. AENOR.

24. EN 14157,(2004) European Committee for Standardization. Natural stone test methods. Determination of the abrasion resistance. AENOR.

25. Conde Vázquez, C.;(2017) Síntesis de arenitas artificiales, Doctoral Thesis, Burgos University, Burgos. 